Marjana Dolšina

\title{
Sveti in posvetni: podobe družine $v$ navezavi na sakralne motive poznosrednjeveške pobožnosti *
}

Ključne besede: družina, otroštvo, Sveta družina, Sveto sorodstvo, Ana Samotretja

1 Uvod

Kljub nespregledljivo pomembni vlogi družine, kjer se izoblikujejo primarni vzorci medosebnih odnosov, ki se v nadaljevanju odslikavajo v širših skupnostih in določajo ritem človekovega bivanja, se religiozno naravnana srednjeveška umetnost zaradi konotacije profanosti z njo neposredno ne ukvarja, zato lahko le prek upodobitev "svetih" spoznavamo njihove zemeljske paradigme.

\section{Pojmovanje družine $v$ poznem srednjem veku}

Pri odkrivanju mnogoterih pojavnih oblik družine, ki jih ponujajo sakralni motivi poznosrednjeveške pobožnosti, že na samem začetku naletimo na problem definicije. Pojem družine je namreč kot predmet proučevanja v svoji nenehni vpetosti v geografski in časovni okvir ob njenem neupoštevanju neizbežno izmuzljiv, hkrati pa zaradi enkratne intimne izkušnje, ki jo ima z njim prav vsak izmed nas, vedno znova sili k subjektivnemu pogledu nanj. Zanke v resnici ne predstavlja ohlapnost ene same definicije, ampak številčnost povsem eksaktnih definicij, ki se pojavljajo glede na točno določen kontekst oziroma konkretno situacijo. ${ }^{1} \mathrm{Za}$ pričujoče razmišljanje povsem zadostuje najširše uveljavljena laična ideja družine, ki v grobem pomeni skupino ljudi, katerih življenja se med seboj najtesneje prepletajo. ${ }^{2} \mathrm{~V}$ tem pogledu se srednjeveška ideja družine v svoji osnovi ni bistveno razlikovala od današnje, le da je sorodstvene

* Pričujoči članek je nastal kot nadaljevanje raziskovanj za diplomsko delo z naslovom Od miniaturnega odraslega do otroka: upodobitve otrok v srednjeveški upodabljajoči umetnosti s posebnim ozirom na ozemlje današnje Slovenije in sosednje pokrajine, na Filozofski fakulteti UL, pod mentorstvom red. prof. ddr. Nataše Golob.

1 Za elemente, ki oblikujejo 14 osnovnih družinskih oblik oziroma 196 življenjskih slogov, gl. Čačinovič-Vogrinčič $(1995,46-47)$.

2 Za strukturiranost srednjeveške družine in njeno občutenje v srednjem veku ter literaturo gl. Herlihy (2004, 192-213), cf. Heller-Schuch (1993, 122-128). 
vezi večkrat preglasila povezanost drugačne vrste. Družinski člani so bili tako poleg ožjih, sorodstveno povezanih posameznikov tudi vsi tisti ljudje, ki so živeli v isti hiši in jedli hrano $\mathrm{z}$ iste mize, pogosto ne oziraje se na krvno sorodstvo (Herlihy, 2004, 192; cf. Borst, 1973, 58-61; Goetz, 1987, 34-64). Kljub temu že Philippe Ariès opozarja na dejstvo, da intimno okolje družine v srednjem veku ni obstajalo, saj se je življenje večinoma odvijalo kar na očeh soseske, ki je posegala tudi na najbolj intimna področja, kot sta spolnost in vzgoja otrok (Ariès, 1991, 489-491). In tudi če so obstajali trenutki, ko so člani družine občutili posebno globoko povezanost, medsebojno naklonjenost in varnost domačega ognjišča, jih zaradi njihove banalne narave v srednjem veku niso pogosto upodabljali.

\section{Motiv Svete družine}

Po besedah Davida Herlihyja lahko prav religiozna praksa postane okno v čustveni svet družine (Herlihy, 2004, 203). Enako so lahko upodobitve Svete družine dobrodošla odslikava pozemskih družin, saj predstavljajo osnovni zgled za njen idealni srednjeveški model. Sveta družina se je v poznem srednjem veku uveljavila kot svež ikonografski motiv, obenem so tudi vsi njeni člani kot posamezniki doživeli velik razcvet svojega kulta (Herlihy, 2004, 203).

V 12. stoletju je Marija postala Mater Omnium, nepogrešljiva mediatrix, njej so verniki lažje zaupali svojo stisko kot odmaknjeno transcendentalnemu božjemu bitju (Herlihy, 2004, 203). V ospredje sta stopila njeno materinsko sočutje (McLaughlin, 2004, 56) in ljubezen, ki je izgubila svoj abstraktni značaj in je našla mesto tudi v upodobitvah sočasne umetnosti. ${ }^{3}$ Podobe Marije $\mathrm{z}$ Jezusom v naročju so vedno bolj ganljivo človeške. Dete se ne pojavlja več le v običajni statični pozi v materinem naročju s pripadajočimi vladarskimi insignijami, temveč je v njegovi podobi mogoče razbrati različna čustvena in razpoloženjska stanja običajnih otrok: iskrivo se smehlja, se igra z žogo ali jabolkom, včasih se nežno prižema k svoji materi (Lechner, III, 1994, 171). Pogosto srečamo tudi upodobitve, na katerih je Marija predstavljena kot doječa mati (Maria Lactans) (Lechner, III, 1994, 158-159), torej pri opravilu, ki so ga v srednjem veku kljub obstoju dojilj imeli za največjo materinsko skrb in odliko (McLaughlin, 2004, 36). ${ }^{4}$ V eni od vizij naj bi s svojim mlekom, ki simbolno predstavlja izvir Božje besede, nahranila samega Bernarda iz Clairvauxa (Roux, 2005, 55). ${ }^{5}$ Njegova posebna

3 Teološke razprave o ljubezni so v 12. stoletju že pisali Bernard iz Clairvauxa, Peter Abelard in Hugo od sv. Victorja (Weise, 1939, 135).

4 Ikonografski tip Mariae Lactans se je sicer najmočneje uveljavil v zahodnoevropski umetnosti v obdobju gotike, a so njegove korenine mnogo starejše in segajo do zgodnjesrednjeveških upodobitev Mariae Galactotrophousae (Menaše, 1971, 693; Lechner, III, 1994, 158-159, 173). 
afiniteta do Marije je bistveno zaznamovala razvoj cistercijanske liturgije ${ }^{6}$ in v povezavi s filozofijo ljubezni izpostavila prav njeno materinsko plat. Iz tega sta se razvila skoraj ljubkovalno ime »Naša ljuba gospa « in motiv Marije zavetnice s plaščem, ki ga srečujemo od 13. stoletja dalje. Leta 1281 je pod njen patrocinij prešla redovna cerkev v Citeauxu, kar je kmalu postalo pravilo tudi za druge cistercijanske cerkve, vsakodnevne maše njej $\mathrm{v}$ čast pa redna praksa. Generalni kapitelj je leta 1335 celo zahteval Marijino podobo na vsakem uradnem pečatniku (Eberl, 2002, 162-164). Humanizacija njene podobe se je v umetnosti italijanskega trecenta združila s prebujajočo se željo po naturalizmu v motivu Device v pričakovanju. ${ }^{7}$ Madonna del Parto je kot vsaka druga nosečnica upodobljena $\mathrm{v}$ udobnih, ravno padajočih oblačilih $\mathrm{z}$ visokim nosečniškim pasom tik pod prsmi. Navdih zanj so mojstri našli v relikviji Sacra Cintola, ki se nahaja v mestecu Prato blizu Firenc (Cassidy, 1991, 91-93). Vzporedno s tem se je začela razvijati tudi druga podoba Marije kot učene ženske (Maria mulier docta) znotraj motiva oznanjenja. ${ }^{8}$ Tega so v poznem srednjem veku še upodabljali kot sveti dogodek, a je v nasprotju s poprej znanimi upodobitvami v nebeškem brezprostorju umeščen v intimo sočasnega meščanskega stanovanja s knjigo kot nepogrešljivim atributom v Marijinih rokah ali naročju oziroma odloženo na bralni pult (Golob, 1998, 1740-1744). Knjiga namiguje na kontemplativnost in poglobljen študij, Marijo pa gledalcu predstavi kot intelektualko svojega časa, enakovreden pendant moškim razumnikom (Golob, 1998, 1743-1744). Motiv oznanjenja, ki se mu pridružijo še prizori učenja branja (Ana uči brati Marijo, Marija uči brati Jezusa), namigujejo na počasi spreminjajoči se pogled na ženske kot razmišljujoče in dejavne sooblikovalke poznosrednjeveške družbe (Golob, 1998, 1745-1753).

Motiv Jezusa Otroka se je začel pojavljati vzporedno z motivom Marije Matere, največkrat v umetnosti cistercijanov (Egger, 1982, 764; cf. Cempura, 1982, 764-768). Frančišek Asiški naj bi si po legendi celo zamislil prve jaslice (Herlihy, 2004, 204), ki postavljajo nebogljenost novorojenega otroka $\mathrm{v}$ središče vernikove pozornosti. ${ }^{9}$ Priljubljenost kulta se je zaradi bolj blage, dostopne in manj avtoritativne inkarnacije Boga na zemlji do pozne gotike le še stopnjevala. Tudi med drugimi svetniki so bile vedno pogostejše vizije, v katerih se je Jezus pojavljal bodisi kot dojenček, razposajen deček ali šolar bodisi kot njihov vrstnik pri igri ali ranljivo dete, ki so ga ljubeče pestovali (Herlihy, 2004, 204). Skupaj z razvojem religioznih praks je tudi profana plat otroštva dobivala vedno bolj pozitivno konotacijo (Herlihy, 2004, 205).

6 Cistercijani so v Mariji prepoznali idealno razmerje aktivnega dela (skrb za družino) in kontemplacije (Roux, 2005, 54).

7 Za upodobitve Device v pričakovanju gl. Cassidy (1991, 91-99).

8 Za upodobitve Marije kot učene ženske gl. Golob (1998, 1739-1754).

9 Za simbolni pomen jaslic v religioznem doživljanju božiča na Slovenskem in uresničitve znotraj ljudske umetnosti gl. Grčar (2007, 185-205). 


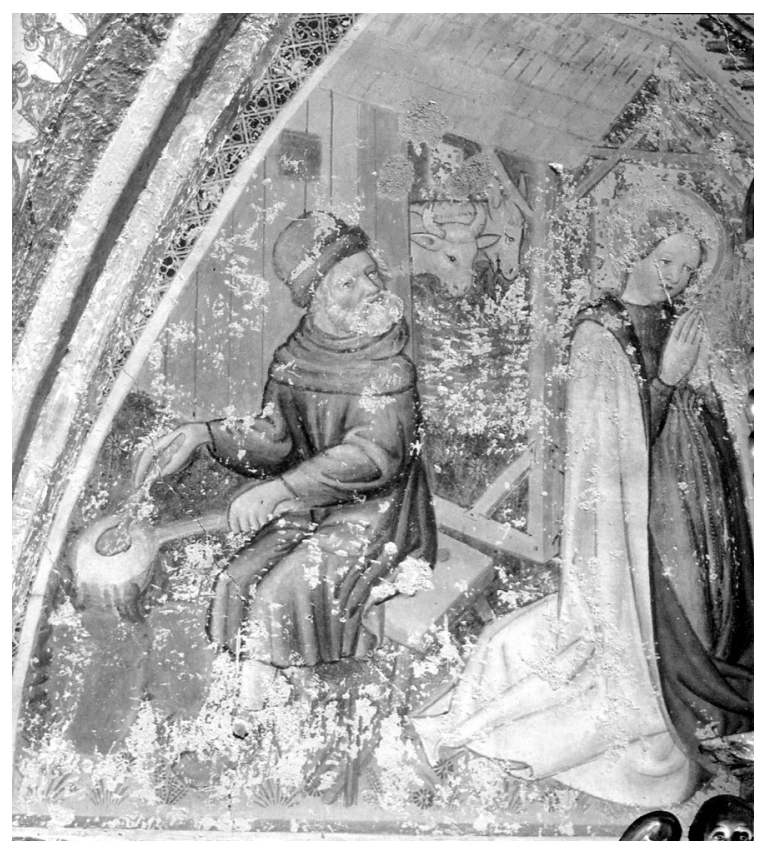

Slika 1: Mojster Bolfgang, Kristusovo rojstvo, vzhodni del severne stranske ladje v romarski cerkvi Marijinega oznanjenja v Crngrobu, 1453, Crngrob.

Vir: Gotika v Sloveniji, 1995, 273.

Tretji član Svete družine, sveti Jožef, je bil po mnenju Davida Herlihyja sprva nepomembna figura znotraj krščanske doktrine, tudi Sveto pismo ga le na kratko omenja (Herlihy, 2004, 205). ${ }^{10}$ Kljub temu Rosemary Drage Hale opozarja, da ga tudi pred razcvetom njegovega kulta v 15. stoletju pisci niso povsem prezrli (Drage Hale, 1999, 103). ${ }^{11}$ Večina cerkvenih očetov ga označuje kot božjega izbranca, ki je sprejel vlogo Marijinega zaščitnika in Jezusovega zemeljskega skrbnika. Osredotočajo se na njegov davidovski izvor in značajske odlike, med katerimi je v ospredju pravičnost, sledijo pa ji razsodnost, vdanost, skromnost, požrtvovalnost in devištvo (Drage Hale, 1999, 103, cf. Sheingorn, 1999, 84). Njihove razprave, predvsem tiste, ki sta jih napisala sveti Avguštin in Bernard iz Clairvauxa, so dobile pomembno mesto v poznosrednjeveških pridigah (Drage Hale, 1999, 103). V likovnih stvaritvah je do konca visokega srednjega veka nastopal le kot stranski akter, ikonografsko dopolnilo $\mathrm{k}$ upodobitvam marijanske pobožnosti. Zato ga v zgodnejših delih, še posebej pa od sredine 14. do sredine 15. stoletja, najpogosteje srečamo v podobi čemernega starca, ki ziba ali hrani otroka, mu kuha ali pripravlja kopel, s čimer je poudarjeno njegovo adoptivno očetovstvo (Drage Hale, 1999, 105-106). V romarski cerkvi Marijinega

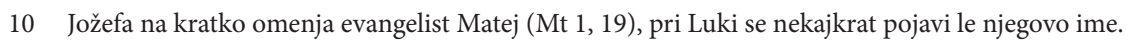

11 Za navedbo vseh besedil o sv. Jožefu gl. Drage Hale $(1999,103)$. 
oznanjenja v Crngrobu najdemo na vzhodnem delu severne stene poklon Svetih treh kraljev s Kristusovim rojstvom iz sredine 15. stoletja, ${ }^{12}$ ki je delo mojstra Bolfganga (slika 1). Danes je ohranjena le še leva polovica prizora rojstva: Marija, ki časti dete, in Jožef pred stajo v ozadju. Precej običajni kompoziciji je avtor dodal zanimiv žanrski detajl Jožefa, ki sedi na nizki leseni pručki in kuha močnik. To kaže na starejše, po Janezu Höflerju v 14. stoletje segajoče interpretacije Jožefa v vlogi gospodinjskega pomočnika (Höfler, 1995, 273). Upodobljen je trenutek njegove nepozornosti, ko z ostrim zasukom glave usmeri svoj pogled proti Jezusu in Mariji, zatopljeni v molitev, medtem pa mu gosta zmes skipi iz posode.

Šele v drugi polovici 15. stoletja je nekoliko šaljive podobe starega varuha (npr. prizor rojstva na Grabowskem oltarju ${ }^{13}$ nadomestil lik vitalnega moža v zrelih letih ${ }^{14}$ (npr. oltar za družino Merode). ${ }^{15}$ Jožef je postal obrtnik in delavec, ki je v polni meri sposoben preživeti svojo družino, pri čemer je humorni vidik postal popolnoma odveč (Drage Hale, 1999, 107-110). Še vedno je sicer lahko prevzemal določeno skrb za otroka, a so ga namesto pri negi dojenčka raje upodabljali pri bolj tipično očetovskih nalogah: opismenjevanju ali urjenju različnih veščin že nekoliko starejšega dečka (Sheingorn, 2004, 288; cf. Drage Hale, 1999, 112). Razloge za takšne spremembe lahko najdemo v sočasnem vzponu meščanskega sloja; upodobitve Svete družine so postajale zrcalna podoba dejanskih meščanskih družin (cf. Sheingorn, 2004, 289), in ker so bile te izrazito patriarhalno naravnane, je posledično tudi Jožef stopil iz Marijine sence in postal pater familias (Drage Hale, 1999, 103, 113). Obenem je celotna zasedba treh članov pomenila tudi zemeljsko paradigmo nebeški Sveti trojici (Drage Hale, 1999, 113; cf. Herlihy, 2004, 206; Atkinson, 1991, 159). Po koncu srednjega veka se je razvoj $\mathrm{v}$ to smer le še stopnjeval. ${ }^{16} \mathrm{~V}$ začetku 16 . stoletja so se začeli pojavljati prizori, na katerih Jožef drži Jezuščka za roko, medtem ko Marije sploh ne zasledimo več. Grafika anonimnega nemškega avtorja iz 15. stoletja (slika 2) je eden najzgodnejših tovrstnih primerov. Kljub Jožefovi vlogi zaščitnika se ob natančnejšem opazovanju podobe zdi, da je v resnici mali Jezus tisti, ki ju vodi, saj z iztegnjenim kazalcem desnice odločno kaže naprej, medtem ko se s pogledom ozira nazaj na svojega zemeljskega skrbnika.

12 Poslikava je signirana in datirana $\mathrm{z}$ letnico 1453 in formalno pripada plastičnemu poznogotskemu slogu, ki je v slovenskih deželah nasledil mehki slog zgodnjega 15. stoletja (Höfler, 1995, 272-273).

13 Reprodukcije Grabowskega oltarja (ok. 1383) (Platte, 1965, 6), ki je delo Mojstra Bertrama, so dostopne na spletu, za dodatna pojasnila gl. Platte (1965).

14 Jožef je kot sinonim varnosti in zaščite postal eden bolj priljubljenih svetnikov v kriznih časih poznega srednjega veka (Herlihy, 2004, 206).

15 Reprodukcije oltarja za družino Merode Roberta Campina (1425-30) (Thürlemann, 2002, 58) so dostopne na spletu, za dodatna pojasnila gl. Thürlemann (2002, 58-69).

16 Od leta 1675 dalje je Jožef zavetnik Kranjske in ostalih habsburških dežel, zato se v slovenski likovni umetnosti pojavlja še pogosteje (gl. Lavrič, 2010, 383-400). 


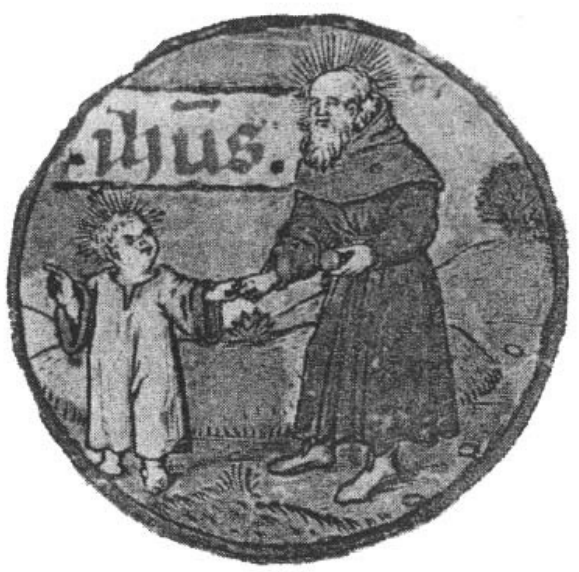

Slika 2: Anonimni nemški avtor, Jožef in Kristus Otrok, 15. stoletje, National Gallery of Art, Washington D.C., Rosenwald Collection. Vir: Medieval Families, 2004, 288.

\section{$4 \quad$ Sorodstvene vezi}

V poznem srednjem veku se je pripadnost ožji družini začela določati s priimkom, ${ }^{17}$ ko se je zaradi porasta prebivalstva $\mathrm{v}$ mestih in uvajanja upravnih seznamov pojavil dvoimenski sistem (Bunc, 1963, 174). Večji del srednjega veka je tako zaznamoval enoimenski sistem $^{18}$ (Bunc, 1963, 174; cf. Borst, 1973, 58), z izjemo plemiških rodbin, ki so že od 11. stoletja dalje svojim imenom dodajale še ime matičnega gradu (Borst, 1973, 60). Med njimi je tvorjenje družinskih dreves predstavljalo običajno prakso za utrditev lastne samopodobe. Medtem ko so bili v zgodnjem srednjem veku predniki obeh staršev v genealogijah še enakovredni, je od 11. stoletja dalje vse bolj dominirala agnatska družinska veja. Odslej so bili moški glavni akterji v družinskih deblih, ženske so predstavljale le manj pomembne stranske poganjke (Sheingorn, 2004, 274). Tudi pri Kristusu so začeli iskati agnatsko linijo prednikov, ki naj bi povzemala vse kreposti in vrline najodličnejšega rodu. Sadove teh prizadevanj začnemo opažati v 11. stoletju v upodobitvah Jesejeve korenike (Iz 11, 1-2), a lahko od 13. stoletja dalje že govorimo o počasnem zatonu tega ikonografskega tipa (Sheingorn, 2004, 273-275). ${ }^{19}$

17 Za razvoj priimkov gl. Bunc (1963, 174-177).

18 Raba priimkov se je vsesplošno uveljavila po letu 1600 zaradi obvezne uvedbe rojstnih in mrliških matičnih knjig (Bunc, 1963, 174), po Borstu pa so se začeli pojavljati v 11./12. stoletju in so bili v 13. stoletju že dodobra razširjeni (Borst, 1973, 60).

19 Za razvoj ikonografskega tipa Jesejeve korenike s slikovnim gradivom in referencami gl. Low (2006) in Thomas $(1994,549-558)$. 
Kot odgovor na patriarhalno zasnovano Jesejevo koreniko se je v zahodnoevropski umetnosti pojavil motiv Svetega sorodstva $\mathrm{z}$ najstarejšimi primeri v angleškem in francoskem knjižnem slikarstvu poznega 13. in zgodnjega 14. stoletja (Esser, 1986, 55; cf. Höfler, 2009, 84), ki je po Janezu Höflerju doživel razcvet okoli leta 1500 (Höfler, 2009, 85). Ikonografsko temelji na svetopisemskih pasažah (Mt 27, 56; Mr 15,40; Mr 3, 18; Lk 6, 15; Jn 19, 25; Apd 1, 13) in drugih besedilih, ${ }^{20}$ vezanih na kult sv. Ane, ki je bil v poznem srednjem veku zelo razširjen (Sheingorn, 2004, 277). Po Zlati legendi naj bi se trikrat poročila (Legenda Aurea, 521), zato Sveto sorodstvo vključuje kar med 17 in 27 članov (Esser, 1986, 16; Höfler, 2009, 84-85). ${ }^{21}$ Martin Lechner kot enega najbolj reprezentativnih primerov navaja Ortenberški oltar iz prve tretjine 15. stoletja, delo anonimnega Mojstra Ortenberškega oltarja, ki pri uresničitvi motiva brez moškega dela sorodstva sledi viziji sv. Colette Boilet (1380-1447) (Lechner, 1994, IV, 163, 165; Atkinson, 1991, 161). ${ }^{22}$ Sveto sorodstvo se je uveljavilo predvsem v nemško govorečem prostoru in ga $\mathrm{v}$ začetku 16. stoletja že lahko najdemo tudi na območju današnje Slovenije. Tabelna slika v tehniki tempere na lesu (ok. 1510) je tipičen primer tovrstne upodobitve in kaže tesne povezave z umetniško dejavnostjo severno od Alp (slika 3) (Vignjevič, 1995, 342-343). ${ }^{23} \mathrm{~V}$ središču se Ani pridružujeta Marija in Jezušček z zanimivim detajlom koralne ogrlice. $\mathrm{V}$ obdobju prehoda iz srednjega veka v renesanso je bila meja med religioznostjo in praznoverjem pri rizičnih segmentih življenja, torej rojstvu otrok in njihovi zgodnji mladosti, še zelo nejasno začrtana. Zaradi visoke smrtnosti so jih med drugim skušali zavarovati z raznovrstnim apotropejskim nakitom, posebnimi predmeti in kratkimi obredi. Še posebej priljubljenim koralam se ni mogel izogniti niti Jezus v vsej svoji božanski naravi (Jaritz, 1986, 164). Levo in desno od njega se koncentrično vrstijo njegovi zemeljski predniki, katerih imena izvemo z napisnih trakov (gl. Höfler, 2009, 85). Kljub vtisu sproščene celote nizka ograja sliko kompozicijsko strogo razdeli na dva dela. Moški sorodniki so v nasprotju z Ortenberškim oltarjem vključeni v kompozicijo, a so skupaj s peščico manj pomembnih žensk potisnjeni v ozadje (cf. Sheingorn, 2004, 278); le Joahim in Jožef, prvi z oprto roko, drugi z robom svojega plašča, segata v vsebinsko pomembnejši sprednji plan. Ta je namenjen stari materi Ani s tremi hčerkami - Marijo na desni, Marijo Kleofo na levi ter Marijo Salomo na skrajni desni - in sedmimi vnuki. S tem ko je avtor postavil v ospredje same ženske, jih tako rekoč okronal s svetniškimi siji in jim na obraze pričaral izraz jasnega zavedanja o spoznanju skrivnosti življenja, jih je označil z neko

20 Legenda Aurea (Legenda Aurea, 520-521), De laudibus sanctissime Anne tractatus (Esser, 1986, 32) ipd.

21 Za razčlembo celotnega Svetega sorodstva gl. Legenda Aurea (521), za natančnejši razvoj motiva gl. Esser (1986); Sheingorn (2004, 273-301); Atkinson (1991, 160-161); Höfler (2009, 84); Lechner (1994, IV, 163-168); Menaše (1971, 2087-2088).

22 Za Ortenberški oltar, vključno z reprodukcijo, gl. Beeh (1970?); Grötecke (2007, 452).

23 Za ugotavljanje avtorstva in provenienco gl. Vignjevič $(1995,342)$. 
posebno samozavestjo. Zdaj so lahko tudi vse zemeljske ženske prepričane v lastno nenadomestljivost in hkrati svetost, za katero ni več nujno potrebno deviško življenje znotraj samostanskih zidov, ampak jo lahko uresničijo prek materinstva. Čeprav se je bitka za svetost med obema poloma na koncu srednjega veka prevesila na stran slednjega (Atkinson, 1991, 144-145), je ideal še vedno predstavljala njuna združitev $\mathrm{v}$ deviški materi Mariji, ki je zato tu upodobljena brez pokrivala, z razpuščenimi lasmi. V istem času so se začele pojavljati še druge svetnice matere, ki so imele svoje zemeljske potomce ali so v svojih vizijah celo rodile Jezusa in nato zanj skrbele. $\mathrm{Na}$ materinstvo niso več gledali le v strogo fizičnem smislu, ampak so ga povzdignili v mistični dogodek, ki je nerazdružljivo povezan s spiritualnostjo in božjim blagoslovom (Atkinson, 1991, 162-165). V ospredju je upodobljenih še vseh sedem Aninih vnukov, pri katerih je mojster upošteval različne časovno pogojene segmente otroštva; pri tem se je zavedal vseh plati odraščanja in hkratnega spreminjanja od novorojenčka v dobi infantiae do dečka v zgodnji puberteti (pozna pueritia). Jezus in Simon Zelot (ob skrajnem levem robu) sta poleg Servacija in Janeza Krstnika (levo in desno v ozadju) najmlajša predstavnika sorodstva na sliki in sta zato prikazana gola. Obdobje detinstva je v poznem srednjem veku namreč veljalo za čas popolne nedolžnosti, ko je bil otrok po krstu že očiščen izvirnega greha in obenem še ni bil zmožen grešiti po lastni volji (Heller-Schuch, 1993, 122), zato tudi ni bilo potrebno, da bi se svoje golote sramoval. Podobno stališče do otrok nam podaja Sveto pismo, ki jih označuje kot najbolj iskrene in goreče med verniki, Jezus pa jih v svojih naukih celo postavlja za zgled odraslim (Ps 127, 3; Mr 10, 13-16; Mt 18, 1-6). Avtor se je otroški figuri posvetil tudi v oblikovnem smislu in upošteval drugačna telesna razmerja: glava je $\mathrm{v}$ primerjavi $\mathrm{z}$ ostalim telesom večja, okončine so krajše in polne drobnih oblin, lasje so svilnati in praviloma svetlih, pšeničnih odtenkov, pri mlajših še zelo kratki, pri starejših nekoliko daljši. Janez Evangelist v desnem spodnjem kotu predstavlja naslednje starostno obdobje. Njegovo telo že ogrinja tanka bela halja, običajna otroška oprava tistega časa. Zaradi lesene hojice, s katero se uči hoditi, lahko njegovo starost ocenimo na okoli leto dni, obdobje poznega detinstva, ki so ga srednjeveški pisci označevali tudi kot čas rasti zob (dentium plantativa). Judo Tadeja, Jožefa Pravičnega oziroma Barnabo in Jakoba Mlajšega na spodnjem levem delu lahko uvrstimo v obdobje zgodnje pueritiae, torej okoli sedmega leta starosti. Vsi so že odeti v prava oblačila, čez srajco imajo ogrnjen do sredine meč segajoč plašček oziroma tuniko, ki jo pri Jakobu Mlajšemu in Barnabu dopolnjujeta pas in nanj pripeta opasna torbica, namenjena raznovrstnim drobnarijam, ki jih nosita s seboj. Otrok je pri tej starosti že dovolj odgovoren, da pri sebi hrani denar in poseduje druge osebne predmete. Sem lahko sodijo tudi šolski pripomočki (trstika, tintnik, kreda, tablica ipd.), saj se je za večino pouk pričel ravno v tem času. Barnaba, ki je najstarejši sin Marije Kleofe, nosi že odraslim oblačilom podoben plašč svetle kremne barve, obšit z bogato temno obrobo, obenem so njegovi lasje dovolj dolgi, da pokrivajo 
vrat. Njegovo podobo je mojster igrivo dopolnil z žanrskim detajlom hrušk. Nekaj jih je deček nabral v notranjo stran zgornjega oblačila, eno ponuja svojemu mlajšemu bratu Simonu Zelotu. Zdi se, da za njegovo pozornost tekmuje z Judo Tadejem, ki ga drži za roko. Očitno so bili že v srednjem veku najmlajši otroci ljubljenci ostalih družinskih članov. Podrobna predstavitev posameznih stopenj otroštva se na sliki zaključi z Jakobom Starejšim v zgodnjih najstniških letih. Na prehodu iz srednjega $\mathrm{v}$ novi vek bi to pomenilo pozno deško ali zgodnjo najstniško dobo, saj je meja med obdobjem pueritiae in adolescentiae najmanj jasno določena. Njegova pričeska je daljša od ostalih in sega prav do ramen, tunika, v katero je odet, sega do gležnjev. Ker gre še vedno za otroka, ki se igra s svojimi vrstniki, je v pasu nekoliko privihana, da ga blago ne ovira pri gibanju. Jakob Starejši edini izmed otrok ni bosonog, ampak je, kot odrasli, obut v škornje iz svetlega usnja. Ta detajl nam jasno pove, da je pred nami podoba odraščajočega dečka, ki se bo kmalu moral osamosvojiti, kljub temu da tu še vedno išče zavetje $\mathrm{v}$ materinem objemu. ${ }^{24}$

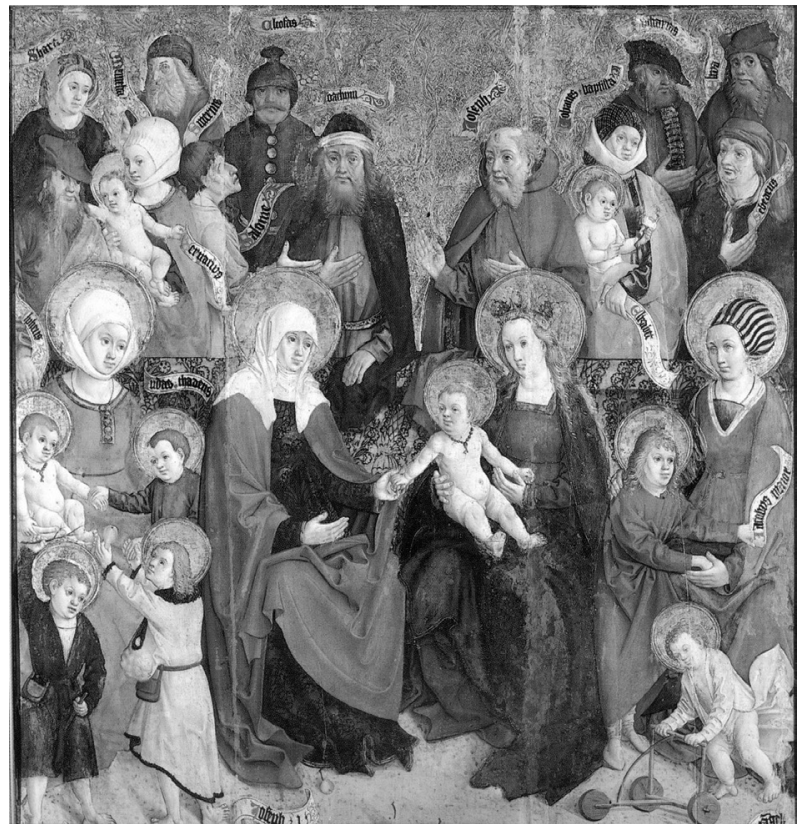

Slika 3: Mojster iz Okoličnega, Sveto sorodstvo, ok. 1510, Narodni muzej, Ljubljana. Vir: Gotika v Sloveniji, 1995, 342.

Čeprav bi zlato brokatirano ozadje utegnilo namigovati na simboličnost upodobljenega, lahko glede na način upodobitve figur in izpeljavo osnovne ideje Svetega sorodstva

24 Za nego otrok, oblačilne navade otrok in igrače v srednjem veku gl. Kühnel $(1967,10)$ in Goetz (1987, 61-64), za razvoj motiva otroka v umetnosti in literaturi gl. Arnold (1980, 59-66). 
na zelo osebno koncipirani ravni sliko razumemo kot podobo poznosrednjeveške meščanske družine (cf. Höfler, 2009, 85; Esser, 1986, 36-39). Neposredni realizem v obrazih, oblačilih, držah in dejavnostih figur je še posebej očiten pri upodobitvah otrok v ospredju, ki jih odlikujeta množica žanrskih detajlov in živahna socialna interakcija. Prav zaradi te realne odslikave sočasne družbe nas ne sme presenetiti, da so se v prvi polovici 16. stoletja množično pojavljale upodobitve članov pomembnejših plemiških družin v vlogi Svetega sorodstva. Striglov portret družine cesarja Maksimilijana iz leta 1515 (slika 4), ki ni osamljen primer, tako ne more biti le navaden portret, ampak gre za očiten prenos sakralnega motiva $\mathrm{v}$ profano rabo. ${ }^{25}$ Mnogofiguralni motiv pogosto srečamo tudi v obliki redukcije na njegovo pomensko središče kot Ano Samotretjo z Ano, Marijo in Jezusom, ki je v 15. stoletju, enako kot motiva Svetega sorodstva in Marije Oznanjenja kot učene ženske, na vrhuncu priljubljenosti. ${ }^{26}$

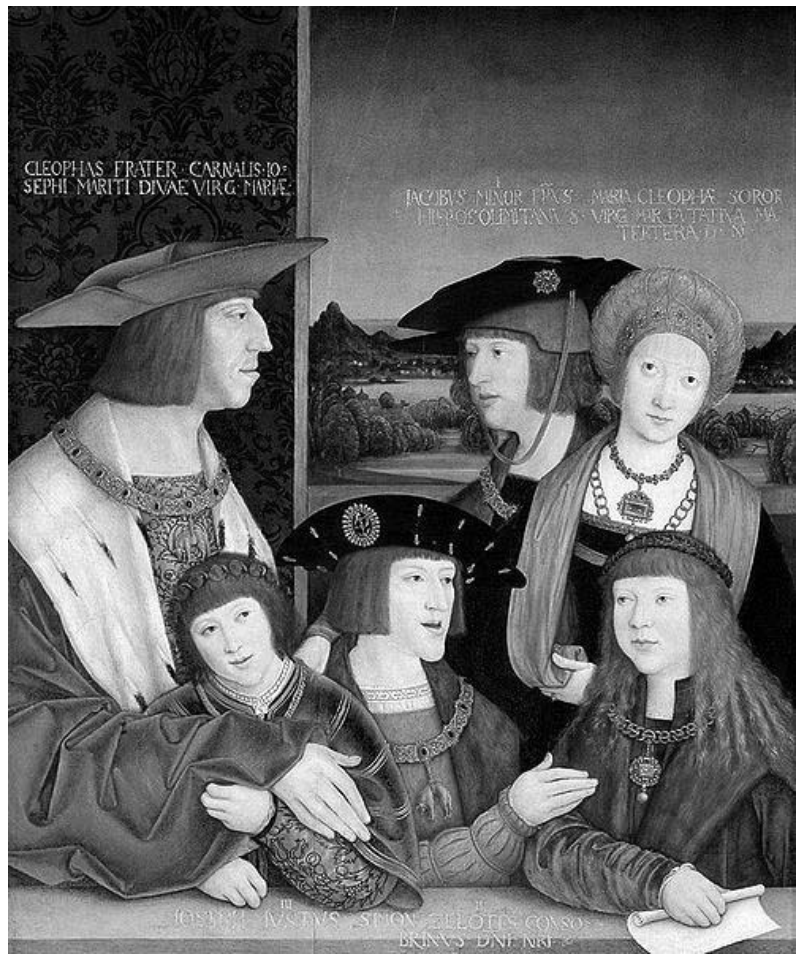

Slika 4: Bernhard Strigel, Portret družine cesarja Maksimilijana, ok. 1515, Kunsthistorisches Museum, Dunaj.

Vir: http://www.wikipaintings.org/en/bernhard-strigel/holy-family\#supersizedartistPaintings-274476.

25 Za dodatne primere in pojasnila gl. Sheingorn (2004, 290-294); Esser (1986, 116-117); Lechner (1994, IV, 168). Za portret družine cesarja Maksimilijana Bernharda Strigla gl. Otto $(1964,101)$. 


\section{Zaključek}

Umetnost srednjega veka, ki je v svojem stremljenju za božjim na prvi pogled predana le religioznim temam in zanemarja dogajanje »tu in zdaj«, nam v 15. in 16. stoletju prav znotraj sakralnih motivov postreže $\mathrm{z}$ raznobarvno paleto žanrskih detajlov. V upodobitvah motiva Svete družine tako zlahka najdemo reminiscence na ustrezno idealizirano srednjeveško družino in njene osnovne predstavnike. $\mathrm{Na}$ enak način postanejo prizori Svetega sorodstva ob koncu srednjega veka vedno bolj pozemsko naglašeni: sveta Ana deluje kot zaupnica svojim trem hčeram, ki se zabavajo ob pogledu na otroke pri igri, medtem se ostali člani sorodstva sproščeno pomenkujejo, kot da bi zatopljeni v pogovor pozabili na prisotnost slikarja.

Vsa prizadevanja za življenjsko-realistične ponazoritve družinskih scen 15. in 16. stoletja so obrodila sadove v 17. stoletju, ko se zasidra mistični motiv svetega otroštva $\mathrm{z}$ otroškimi in družinskimi portreti, dokler se ni v 18. in še posebej 19. stoletju dokončno uveljavil kult otroštva, ki ni bil več vezan le na posamezne sakralne motive, ampak se je razširil na celotno umetnost in, širše gledano, tudi na celotno družbo (Ariès, 1991, 156, 488; Belsey, 2005, 66; Cevc, 1975; Green, 2007, 1-20).

\section{Viri}

Jacobus de Voragine, Legenda Aurea (iz latinščine v nemščino prevedel Richard Benz), Gütersloh 1999.

Sveto pismo stare in nove zaveze: slovenski standardni prevod z devterokanoničnimi/ apokrifnimi knjigami, Ljubljana 2003.

Slika 1: Gotika v Sloveniji (ur. Höfler, J.), Ljubljana, Narodna galerija, 1. 6.-1. 10. 1995, Ljubljana 1995, str. 273.

Slika 2: Medieval Families: Perspectives on Marriage, Household \& Children (ur. Neel, C.), Toronto 2004, str. 288.

Slika 3: Gotika v Sloveniji (ur. Höfler, J.), Ljubljana, Narodna galerija, 1. 6.-1. 10. 1995, Ljubljana 1995, str. 342.

Slika 4: dostopno na http://www.wikipaintings.org/en/bernhard-strigel/holyfamily\#supersized-artistPaintings-274476.

\section{Literatura}

Ariès, P., Otrok in družinsko življenje v starem režimu, Ljubljana 1991.

Arnold, K., Kind und Gesellschaft in Mittelalter und Renaissance: Beiträge und Texte zur Geschichte der Kindheit, München 1980. 
Atkinson, C. W., The Oldest Vocation: Christian Motherhood in the Middle Ages, New York 1991.

Beeh, B., Meister des Ortenberger Altares, v: Gemälde, Hessisches Landesmuseum, Darmstadt, Darmstadt 1970?.

Belsey, H., Parential Affection, Apollo CLXII/522, 2005, str. 66-67.

Borst, A., Lebensformen im Mittelalter, Frankfurt na Majni-Berlin-Dunaj 1973.

Bunc, S., O nastanku, razvoju in pomenu priimkov, Jezik in slovstvo 8 (6), 1963, str. 174-177, http://www.dlib.si/?URN=URN:NBN:SI:DOC-QKMIAOTP [5. 8. 2012].

Cassidy, B., A Relic, Some Pictures and the Mothers of Florence in the Late Fourteenth Century, Gesta 33 (2), 1991, str. 91-99.

Cempura, H., Weihnachtsbräuche in dem Klarissenkloster in Stary Sacz in ihrer Verbindung zu den Krippenfiguren, v: 800 Jahre Franz von Assisi: Franziskanische Kunst und Kultur des Mittelalters (ur. Kühnel, H. in drugi), Krems-Stein, Minoritenkirche 15. Mai-17. Oktober 1982, Dunaj 1982, str. 764-768.

Cevc, A., Otrok in družina v slovenski likovni umetnosti, Ljubljana, Narodna galerija, 20. 5.-24. 5. 1975, Ljubljana 1975.

Čačinovič-Vogrinčič, G., Pomembna variabla raziskovanja v psihologiji družine: pravica do resničnosti, Psihološka obzorja 4 (4), december 1995, str. 45-54, http:// www.dlib.si/?URN=URN:NBN:SI:DOC-E5PWI4L5 [5. 8. 2012].

Drage Hale, R., Joseph as Mother: Adaptation and Appropriation in the Construction of Male Virtue, v: Medieval Mothering (ur. Parsons, J. C. in drugi), New York 1999, str. 101-116.

Eberl, I., Die Zisterzienser: Geschichte eines europäischen Ordens, Stuttgart 2002.

Egger, H., Volksfrömmigkeit, v: 800 Jahre Franz von Assisi: Franziskanische Kunst und Kultur des Mittelalters (ur. Kühnel, H. in drugi), Krems-Stein, Minoritenkirche 15. Mai-17. Oktober 1982, Dunaj 1982, str. 764.

Esser, W., Die Heilige Sippe: Studien zu einem spätmittelalterlichen Bildthema in Deutschland und den Niederlanden, Bonn 1986.

France, J., Medieval Images of Saint Bernard of Clairvaux, Kalamazoo, Michigan 2007.

Goetz, H. W., Leben im Mittelalter: vom 7. bis zum 13. Jahrhundert, München 1987.

Golob, N., The Annunciation as a Representation of Mulier Docta in Late Medieval Art, v: Interpretation of the Bible (separat), Ljubljana 1998, str. 1739-1754.

Grčar, L., The Nativity Scene and Fidelity in the Family, Traditiones 36 (1), 2007, str. 185-205, http://www.dlib.si/?URN=URN:NBN:SI:DOC-P7Z4OH05 [5. 8. 2012]. 
Green, A., French Paintings of Childhood and Adolescence 1848-1886, Aldershot 2007.

Grötecke, I., Retabel aus Ortenberg, v: Geschichte der bildenden Kunst in Deutschland, Bd. 3 (Gotik) (ur. Klein, B.), München 2007, str. 452.

Heller-Schuch, B., Kindheit im Mittelalter und in der frühen Neuzeit, v: Familie: Ideal und Realität (ur. Vavra, E.), Niederösterreichische Landesausstellung, Barockschloss Riegersburg 93, Horn 1993, str. 122-128.

Herlihy, D., The Making of the Medieval Family: Symmetry, Structure, and Sentiment, v: Medieval Families: Perspectives on Marriage, Household \& Children (ur. Neel, C.), Toronto 2004, str. 192-233.

Höfler, J., Mojster Bolfgang in njegov krog, v: Gotika v Sloveniji (ur. Höfler, J.), Ljubljana, Narodna galerija, 1. 6.-1. 10. 1995, Ljubljana 1995, str. 272-273.

Höfler, J., Mojster iz Okoličnega (krog): Sveto sorodstvo, ok. 1500, v: Umetnine iz Prekmurja: od romantike do modernizma (ur. Balažic, J.), Murska Sobota 2009, str. 84-86.

Jaritz, G., Leben, um zu leben, v: Alltag im Spätmittelalter (ur. Kühnel, H.), GradecDunaj- Köln 1986, str. 157-188.

Kühnel, H., Die materielle Kultur des Spätmittelalters im Spiegel der Zeitgenössischen Ikonographie, v: Ausstellung Gotik in Österreich (ur. Kühnel, H.), Krems, 19. maj15. oktober 1967, Krems 1967, str. 7-36.

Lavrič, A., Kult in likovne upodobitve sv. Jožefa, zavetnika Kranjske, pri ljubljanskih diskalceatih, Kronika, časopis za slovensko krajevno zgodovino 58 (2), 2010, str. 383-400.

Lechner, M., pod geslom: Maria, Marienbild, Lexikon der christlichen Ikonographie III, Freiburg-Basel-Dunaj 1994, str. 154-210.

Lechner, M., pod geslom: Sippe, Heilige, Lexikon der christlichen Ikonographie IV, Freiburg- Basel-Dunaj 1994, str. 163-168.

Low, M., Tree of Jesse: A Directory of the Tree of Jesse, Fareham, Hampshire 2006, http:// homepage.ntlworld.com/m.low1/treeofjesse.pdf [5. 8. 2012].

Menaše, L., pod geslom: Ana Samotretja, Evropski umetnostnozgodovinski leksikon: bibliografski, biografski, ikonografski, kronološki, realni, terminološki in topografski priročnik likovne umetnosti Zahoda v 9000 geslih, Ljubljana 1971, str. 61.

Menaše, L., pod geslom: Sveto sorodstvo, Evropski umetnostnozgodovinski leksikon: bibliografski, biografski, ikonografski, kronološki, realni, terminološki in topografski priročnik likovne umetnosti Zahoda v 9000 geslih, Ljubljana 1971, str. 2087-2088. 
McLaughlin, M. M., Survivors and Surrogates: Children and Parents from the Ninth to the Thirteenth Centuries, v: Medieval Families: Perspectives on Marriage, Household \& Children (ur. Neel, C.), Toronto 2004, str. 20-124.

Otto, G., Bernhard Strigel, München, Berlin 1964.

Platte, H., Meister Bertram in der Hamburger Kunsthalle, Hamburg 1965.

Roux, J., The Cistercians, Toulouse 2005.

Sheingorn, P., Appropriating the Holy Kinship: Gender and Family History, v: Medieval Families: Perspectives on Marriage, Household \& Children (ur. Neel, C.), Toronto 2004, str. 273-301.

Sheingorn, P., The Maternal Behavior of God: Divine Father as fantasy Husband, v: Medieval Mothering (ur. Parsons, J. C. in drugi), New York 1999, str. 77-99.

Thomas, A., pod geslom: Wurzel Jesse, Lexikon der christlichen Ikonographie IV, Freiburg-Basel-Dunaj 1994, str. 549-558.

Thürlemann, F., Robert Campin: A Monographic Study with Critical Catalogue, London 2002.

Vignjevič, T., Sveto sorodstvo, v: Gotika v Sloveniji (ur. Höfler, J.), Ljubljana, Narodna galerija, 1. 6.-1. 10. 1995, Ljubljana 1995, str. 342-343.

Weise, G., Die geistige Welt der Gotik und ihre Bedeutung für Italien, Halle-Salle 1939. 
Marjana Dolšina

\section{The Holy and the Earthly: Scenes Depicting Family in Relation to Motifs of Late-Medieval Devotion}

Keywords: family, childhood, Holy Family, Holy Kinship, The Virgin and Child with St. Anne (Anna Selbdritt)

Due to its religious orientation, medieval art did not lay much stress on images of quotidian life, since it was too banal to be placed within the depictions in sacral scenes. In spite of all this, it cannot be claimed that the late-medieval society did not deal with issues of family matters and all other related topics - even if these matters were not discussed in written texts, much less in artistic depictions. Even so, through an attentive observation one can recognize obvious parallels to contemporary earthly life. Therefore, the "Holy" can tell us much about their earthly representatives. The nearest paradigm can be found in the iconography of the Holy Family, which represents an ideal model for a secular medieval family. Wider social structures are richly represented as well, most notably in the motif of the Holy Kinship: Jesus, His relatives, and recent ancestors are distinguished by rich genre details and intensive social interactions as if we were observing an ordinary family meeting. The scenes are often reduced to their core idea: The Virgin and Child with St. Anne. All of the art works discussed in this paper represented bases for further development of genre depictions of the modern era. 